\title{
Tax Ruling Regulations in Poland - Evolution of the Institution and Evaluation of the Regulations
}

\author{
Elżbieta Agnieszka Ambrożej*
}

\begin{abstract}
* Elżbieta Agnieszka Ambrożej, Doctor of Law, Department of Finance and Accounting, College of Finance and Management in Bialystok, Poland, specializes in tax law and tax advisory. Author of numerous articles related to tax law and tax consulting, published in prestigious magazines. Member of the Information and Organization Centre for the Research on the Public Finances and Tax Law in the Countries of Central and Eastern Europe. (e-mail: elzbieta.ambrozej@gmail.com)
\end{abstract}

\begin{abstract}
This contribution deals with tax ruling in Poland, its evolution, evaluation of legal solutions concerning it, as well as the practice of issuing those rulings by competent tax authorities. The main objective of the contribution is to confirm the hypothesis that legal regulations concerning tax ruling provisions and the practice of issuing them did not sufficiently ensure the main purpose of the ruling, i.e. uniformity of application of tax law by the fiscal apparatus, as well as legal security of taxpayers. The research used a dogmatic and legal research method, which was supplemented by an analysis of the case law of administrative courts and the Constitutional Tribunal, as well as the existing statistical analysis.
\end{abstract}

Keywords: uniformity in the application of tax law; general tax ruling; individual tax ruling; amendment, annulment or expiration of the tax ruling

\section{Introduction}

The institution of tax ruling in Poland has been functioning since 1998. It is regulated by the Act of 29 August 1997, The Tax Ordinance ${ }^{1}$ (hereinafter referred to as TO). The main reason for the introduction of this institution was the increasing complexity of the Polish tax law, which in turn translated into the growing complexity of economic relations and phenomena, as well as fears of taxpayers' efforts to circumvent tax law and avoid taxation. ${ }^{2}$ Additionally, the taxpayer's self-calculation method being adopted in the Polish tax law transferred the burden of performing complicated and risky activities in the application of tax law, such as how to determine the provisions of both material and procedural tax law, their interpretation and application in relation to the actual state of affairs to the taxpayer. It created a threat to the legal security of the individual, who bears the risk and consequences of possible mistakes or errors made while calculating the tax. ${ }^{3}$ These circumstances required the introduction of regulations that would prevent the tax authorities from issuing different decisions in the same factual and legal circumstances, and on the other hand would allow the taxpayer to obtain professional support provided by tax authorities. 
The Tax Ordinance, in its original wording, ${ }^{4}$ provided for two types of tax rulings: official tax ruling and written information on the scope of application of tax law provisions.

Written information was issued by the competent tax authority of the first instance at the written request of the taxpayer, payer, and collector in their individual cases. The reason for introducing them was the resignation of the legislator from the concept of broad information to taxpayers on the provisions of tax law. ${ }^{5}$ According to the adopted principle of information (Article $121 \S 2$ of the TO) the tax authorities are obliged, at the party's request, to provide only the necessary information on the tax law and only those that are related to the subject of the proceedings, hence the taxpayer's (payer's, collector's) right to obtain written information was to supplement the above principle.

Official tax rulings of the Minister of Finance (MF) constitute a specific legal aid in the interpretation of complicated tax law provisions ${ }^{6}$ both for citizens and tax authorities. They are the resolution of an abstract problem that occurred in the field of application of tax law. ${ }^{7}$ The purpose of introducing them was for the MF to ensure uniformity in the application of tax law by all tax authorities, in case of discrepancies in the practice of their application.

Uniformity in the application of provisions in tax law is of particular importance - it is a condition for the implementation of the principle of equality and justice of taxation. ${ }^{8}$ It ensures that all taxpayers who are in the same legal and actual status will be treated equally by the tax authorities, which means they will bear the same tax burden. It also supports the implementation of the principle of taxpayers' certainty of taxation and their legal security, as it enables them to decide on their actions on the basis of full knowledge of the premises of the tax authorities and the legal consequences that their actions may entail..$^{9}$ The MF's tax rulings also serve to deepen citizens' trust in tax authorities and strengthen the proper implementation of taxpayer's rights in tax proceedings. The obligation to publish those means that citizens and tax authorities may obtain information on the manner of tax rulings of specific tax law provisions, and that compliance with them must not cause any negative consequences.

The article will present the evolution and attempt to evaluate MF's tax ruling. Individual tax rulings will be discussed only to the extent to which they complement the main objective of general tax rulings - ensuring uniformity in the application of tax law by tax authorities. Due to the complexity of the issue of individual tax ruling, the article refers only to tax rulings issued by the state tax administration agencies, it does not deal with tax rulings issued in terms of the attribute of the tax authorities of local government units.

\section{Official Tax Rulings in the Period from 1 January 1998 to 30 June 2007}

Initially (from 1998 till 2002), Art. 14 of the TO on the official MF was far too general and imperfect. It stated that official tax rulings were made to ensure uniform application of tax law by tax authorities and fiscal control authorities. The article did not regulate the legal character of official taxes, the manner of issuing them and the scope of their content, only that those tax rulings were to be made taking into account the case law of courts and 
the Constitutional Tribunal decisions; and if discrepancies in the case law were found, the MF was to notify the competent court or authority that could apply measures to eliminate the discrepancies. The MF's tax rulings were published in the Ministry of Finance's Tax Bulletin.

The TO did not specify to whom the tax rulings of the MF are directed, but it stated that the taxpayer's compliance with the official tax ruling (only) could not harm them. At the same time, the provisions of the TO did not indicate any situations that could be considered harmful to the taxpayer, nor did they regulate the manner in which the tax authority should act in case of negative consequences of the taxpayer's compliance with the MF's tax ruling.

As a result of the amendment of the TO on 1 January $2003,{ }^{10}$ the provision of Art. $14 \S 2$ of the TO determined that the MF's tax rulings are the ones addressed to tax authorities and fiscal control authorities regarding tax law problems and they bind tax authorities and fiscal control authorities. Giving the MF's tax rulings binding force for tax authorities and fiscal control authorities had far-reaching consequences. That tax ruling, as incontestable, obliged the authorities (both the first and the second instance) to apply it, i.e. to proceed and rule in accordance with its content. Overturning the vitiated tax ruling could take place only if the taxpayer (the payer, collector) appealed against the final decision to the Supreme Administrative Court (SAC), which violated the principle of two instances of tax proceedings. ${ }^{11}$ In the literature on the subject, it is stated that noncompliance with the binding tax rulings of tax authorities created a gross violation of the principle that tax proceedings should be led in the way that was raising citizens' confidence in the state authorities, in connection with Art. $121 \S 1$ of the TO. ${ }^{12}$ On the other hand, the official tax rulings are not universally binding sources of law (Article 87 of the Polish Constitution provides for their closed catalogue) so they cannot constitute a legal basis for a tax decision. They should be treated only as guidelines of the MF, how to understand the law. ${ }^{13}$ As a result, this provision, in part stating that the MF's tax rulings bind tax authorities and fiscal control authorities, was considered by the Constitutional Tribunal (judgment of 11 May $2004^{14}$ ) to be inconsistent with the Constitution of the Republic of Poland and on 31 May 2004 lost its binding force.

The amended Art. 14 of the TO exempted the MF from the obligation to notify the courts or the body that could apply measures to remove discrepancies in case law. In addition, it was specified that the MF does not tax rule in individual cases of taxpayers, payers or collectors, which unequivocally defined the abstract nature of these tax rulings.

Protection due to compliance with the MF's official tax ruling was granted to the payer and collector (except the taxpayer). However, it has been added that compliance with the tax ruling does not exempt the taxpayer, payer or tax collector from the obligation to pay tax. This regulation clearly indicated that the MF's tax ruling, although not binding for the taxpayer (payer, collector), protected him only if he behaved according to its content, even if it was incorrect. The taxpayer's (payer's, collector's) compliance with erroneous tax ruling was to have the effect that no proceedings in cases of fiscal offences or fiscal misdemeanours will be instituted against them, and the proceedings instituted in these cases will be dismissed, and that no other consequences, such as no default interest will be charged, or they will not pay the so-called additional liability, will they bear. 
In addition, the compliance of a taxpayer, payer or tax collector to the tax ruling could also constitute a premise for the cancellation of tax arrears.

Another significant change in the regulations governing the institution of tax ruling took place at the beginning of the year 2005. ${ }^{15}$ The MF was to make official tax rulings, taking into account not only judgments of the courts and the Constitutional Tribunal, but also of the European Court of Justice ${ }^{16}$ (Art. $\$ 1$ p.2 of the TO). In addition, Art. $14 \$ 2$ of the TO defined that the official MF's tax rulings are all the explanations of the content of applicable tax law, addressed to tax authorities and fiscal control authorities, regarding tax law problems (excluding tax rulings in individual taxpayer cases). This provision also provided that MF tax rulings and their amendments thereto would be published in the Official Journal of the Minister of Finance.

The principle stating that the compliance of a taxpayer, payer or a collector with the tax ruling must not be harmful to them, has also been extended to the taxpayer's legal successor and third parties responsible for tax arrears.

\section{General Tax Rulings in the Period from July 1, 2007 to the Current Legal Status}

A change in the structure of institutions of official tax ruling took place on 1 July $2007 .{ }^{17}$ The previous official MF tax rulings took the form of general tax rulings, and written tax rulings - of individual tax rulings. The provision of Art. $14 \mathrm{a} \S 1$ of the TO, specifying the competences of the MF in the field of issuing general tax rulings, was amended several times, but in fact retained its shape and meaning in substance.

As a result of the tax administration reform (TAR), since 1 March $2017^{18}$ general tax rulings have been issued by the MF in order to ensure a uniform application of the tax law by tax authorities. They should include a description of the issue in relation to which the tax law is ruled, as well as an explanation of the scope and manner of applying the interpreted tax law provisions to the described issue together with legal justification (Article $14 \mathrm{a} \S 1$ a of the $\mathrm{TO}^{19}$ ).

Since January 2012, ${ }^{20}$ general tax rulings have been issued by the MF not only ex officio but also upon request (Article $14 \mathrm{a} \S 1$ of the TO). In principle, the TO has not provided for any restrictions as regards entities entitled to submit a claim with one exception, public administration bodies are not entitled to submit applications (Article $14 \mathrm{a} \oint 1 \mathrm{~b}$ of the TO). Applications for a general tax ruling shall be submitted on an official form, and a template thereof, in accordance with the instruction of Art. $14 \mathrm{a} \$ 11$ of the TO, shall be specified by MF. ${ }^{21}$ A fee of PLN 40 (Article $14 \mathrm{~d}$ in connection with Article $14 \mathrm{a} \$ 9$ of the TO) shall be paid within seven days from the date of submitting the application (Article $14 \mathrm{f}$ in relation to Article $14 \mathrm{a} \S 9$ of the TO). The fee shall be returned only in the case of issuing a general tax ruling, within seven days from the date of its publication (Article $14 \mathrm{a} \$ 8$ of the TO).

According to Art. $14 \mathrm{a} \$ 2$ of the TO an application for issuing a general tax ruling, in addition to the data identifying the applicant, should contain justification of the need to issue a general tax ruling, in particular: 
- presentation of the issue and indication of tax law provisions requiring the general tax ruling, and

- indication of non-uniform application of tax law provisions in specific decisions, decisions and individual tax rulings issued by tax authorities and fiscal control authorities (in connection with TAR currently only by tax authorities) in the same factual circumstances or future events and in the same legal statuses.

It seems that meeting the conditions for submitting an application for a general tax ruling is even "prohibitive". While the presentation of the issue and indication of tax law provisions requiring a general tax ruling does not raise any objections, the applicant's indication of non-uniform application of tax law provisions in specific decisions, decisions issued by tax authorities in the same factual circumstances or future events and in the same legal statuses throughout the country may be extremely difficult to comply with. ${ }^{22}$ This requires the applicant to find appropriate decisions or rulings, for which it is necessary to be aware not only of their existence (in accordance with Article 129 of the TO, the access to the case file, including decisions and rulings, is reserved exclusively for parties to proceedings, which significantly limits the knowledge about them and their availability), but also their content and whether they were issued in the same factual circumstances or future events (i.e. according to the linguistic interpretation, 'identical', 'unchangeable', 'uniform', 'equivalent'). It means that in practice, the indication of non-uniform application of tax law provisions may be limited only to individual tax rulings which, pursuant to the Act (Article 14i $₫ 3$ of the TO) together with the application for a tax ruling, are published in an anonymous version in the Public Information Bulletin. As the administrative courts emphasize, the existence of inconsistent individual tax rulings determines the necessity of issuing a general tax ruling at the taxpayer's request, ${ }^{23}$ however, issuing two different individual tax rulings, one of which, within the time limit of issuing a general tax ruling, becomes incorrect pursuant to Art. $14 \mathrm{e} \S 1$ of the TO changed - to the extent consistent with the other - does not constitute a non-uniform application of law in individual tax rulings referred to in Art. $14 \mathrm{a} \$ 2$ point 2 of the aforementioned Act. ${ }^{24}$

Art. $14 \mathrm{a} \$ 3$ of the TO made issuing the general tax ruling dependent on the fulfilment of an additional condition. On the day of submitting the application for it issuance, in the cases indicated in the application, no tax proceedings or control proceedings by the fiscal control authority may be conducted, or no appeal or complaint was filed against the decision or provision (currently, if no tax proceedings, tax control, customs and tax control are conducted, or no appeal or complaint was filed against the decision or provision). In order to verify the fulfilment of this condition, tax authorities, upon the written request of the MF, are obliged to submit files regarding the decisions, provisions and individual tax rulings immediately (Article $14 \mathrm{a} \$ 7$ of the TO)

At the beginning of 2012, the Ministry of Finance, acting on the basis of the delegation of Art. $14 \mathrm{a} \S 10$ of the TO, in order to improve the service of applicants, authorized five Directors of Tax Chambers (depending on the scope of cases) to issue, as the first instance authority, decisions on leaving without consideration requests for general tax rulings, and to submit written requests to tax authorities and fiscal control authorities to provide the files regarding decisions, provisions and individual tax rulings indicated in the application 
for issuing general tax ruling. ${ }^{25}$ Currently, as a result of the TAR, such authorization is held by the director of the National Tax Information (NTI) ${ }^{26}$ The NTI director is responsible for the preliminary assessment of the submitted application (including checking whether the application has been addressed to the competent authority and whether the application fee has been paid) and verifying compliance with the statutory prerequisites for consideration of the application. Failure to comply with these conditions shall result in the application not being considered (Article $14 \mathrm{a} \$ 4 \mathrm{TO}$ ). This applies:

- if the application does not present the issue and the tax law provisions which require a general tax ruling and does not indicate non-uniform application of tax law provisions in specific decisions, provisions and individual tax rulings issued by tax authorities in the same factual circumstances or future events and in the same legal statuses, or

- if the application does not meet other requirements specified by law (in this case, to the requirements that should be met pursuant to Art. 168 of the TO regarding the manner of submitting the application, the designation of the entity from which it comes, its address, signature), or

- when the issue presented in the application is the subject to a general tax ruling and the legal status has not changed in this respect.

The decision to leave the application without consideration is made by the NTI Director by way of a decision which may be appealed against to the MF. If the application is considered justified and meets the formal requirements, the Director of NTI submits the application of the MF together with the attached acts, i.e. the decisions, provisions and individual tax rulings indicated in the application for a general tax ruling.

General tax ruling should be issued without undue delay, however not later than within 3 months from the date of the receipt of the application. According to Art. 14d of the TO, the dates and periods referred to in Art. $139 \S 4$ of the TO (including periods of suspension of proceedings or delays caused by the fault of the party or for reasons beyond the control of the authority, as well as the period necessary for the transfer of files related to the decisions, provisions and tax rulings indicated in the application) shall not be included in the time limit, which means that the actual deadline for issuing the tax ruling may be longer than 3 months (Article $14 \mathrm{~d}$ in conjunction with Article $14 \mathrm{a} \$ 9$ of the TO).

Submitting an application for a general tax ruling will, in principle, result in nonjurisdictional proceedings, however, in accordance with Art. 14a 9 of the TO, certain provisions on jurisdictional proceedings shall apply to it; including the ones on accordance with the rule of law (Article 120 of the TO), conducting the proceedings in a manner that inspires confidence in the tax authorities (Article $121 \S 1$ of the TO), in compliance with the principle of speed and thoroughness of proceedings (Article 125 of the TO) and transparency of proceedings for its parties (Article 130 of the TO).

Irrespective of whether tax ruling was issued upon the request or ex officio by the MF, it is not binding either for the taxpayer or the tax authorities. 'However, taking into consideration the official subordination and organisational subjection of tax authorities to the minister, one may doubt if they do not become quasi-sources of tax law.27 From the taxpayer's point of view the legal consequences of complying with the tax ruling are of 
fundamental importance. The lack of a binding force of the MF's tax ruling means that the taxpayer may but does not have to use it, as it is not a decision. ${ }^{28}$ However, complying with the tax ruling protects the taxpayer even if it is incorrect.

Since 1 July 2007, compliance with the general tax ruling prior to its amendment may not harm the party who has complied with it, as well as in the event of it not being taken into account in the decision on a tax case (Art. $14 \mathrm{k} \S 2$ of the TO). 'No harm' means that in the case of compliance with a general tax ruling which later has been amended or was not included in the decision of the tax case, no proceedings are instituted in cases concerning fiscal offences or fiscal misdemeanours, and the proceedings initiated in such cases are discontinued and interest on arrears is not charged (Article $14 \mathrm{k} \S 3$ of the TO).

Compliance with the above tax ruling also results in an exemption from the obligation to pay the tax, to the extent resulting from the event being the subject of the ruling. This is the case if the liability has not been properly performed as a result of complying with the ruling which has changed or the ruling not included in the judgment of the tax case, as well as when the tax consequences related to the event which corresponds to the factual circumstances took place after the publication of the general tax ruling (Article $14 \mathrm{~m} \S 1$ of the TO). The scope of this exemption, depends on the tax settlement period - annual, quarterly or monthly (Art. $14 \mathrm{~m} \S 2$ of the TO). Additionally, in a situation described in Art. $14 \mathrm{~m} \S 3$ of the TO, the taxpayer may additionally demand from the tax authority a calculation of the tax, in a decision determining or fixing the tax covered by this exemption, or - in case of paying the tax, calculation of the amount of overpayment.

However, the compliance with tax ruling does not release from the obligation of payment, if the tax consequences related to the event, which corresponds to the factual circumstances being the subject of the ruling, took place before the issuing of the general tax ruling (Article 141 of the TO).

According to the TO, the MF's tax ruling cannot be appealed against by anyone, even if it has been issued upon request. It results from provisions of the TO that a taxpayer may submit an application for a general tax ruling, but not for its amendment. The only entity being entitled to amend the issued tax ruling is the $\mathrm{MF}^{29}$ who may do that ex officio if its inaccuracy has been stated, taking into account, in particular, judicial decisions of courts, the Constitutional Tribunal or the Court of Justice of the European Union.

Since 1 January 2017, the competence of the Ministry of Finance in the field of harmonizing the application of tax law has been extended by the possibility to issue exofficio tax explanations, i.e. general explanations of tax law provisions regarding the application of these provisions (Article $14 \mathrm{a} \S 1$ point 2 of the TO). Tax explanations, similarly to general tax rulings, are issued taking into account the judgments of the courts, the Constitutional Tribunal or the Court of Justice of the European Union. However, their content differs from general tax rulings. General tax rulings contain an official interpretation of the provisions, whereas the essence of tax explanations is linking the content of the provision with its practical application in relation to exemplary situations. ${ }^{30}$ The purpose of introducing tax explanations was to provide taxpayers with the possibility of obtaining a faster protection due to their compliance with the tax explanations, without the need to apply for an individual tax ruling. Identical scope of protection granted by tax explanations and tax rulings is to lead to a reduction in the number of individual tax rulings 
issued in those areas in which sufficient explanations are included in tax explanations. ${ }^{31}$ Tax explanations are included in the Public Information Bulletin, and their change may take place in the mode provided for general tax rulings.

\section{Conclusions}

The basis for introducing the institution of tax ruling was the MF's attempt to ensure uniformity in the application of tax law by the tax authorities, if the practice of its application raises any doubts. Consequently, it was supposed to prevent the tax authorities from issuing diverging individual tax rulings and to reduce the number of such rulings. The tool of unification of tax legislation application has so far been used by the MF to a limited extent. From 1 July 2007 till the end of 2011, when general tax rulings could only be issued ex officio, the MF issued only thirty. This situation has not been improved by the introduction of the possibility of issuing rulings upon request. In the period from 2008 till May 2018, the number of general tax rulings amounted to 78 (in the years: 2008 - 8; 2009 - 7; 2010 - 6; 2011 - 9; 2012 - 14; 2013 - 19; 2014 - 11; 2015 - 12; 2016 - 9; $2017-6 ; 2018-7$ ), out of which 72 were issued ex officio. Since 2012, MF has issued only 6 tax rulings upon request (in the years: $2012-3 ; 2013-1 ; 2015-1 ; 2016-1$ ). According to the data of the Tax Information Office for the years 2013-2016, it appears that a great part of the submitted applications for a general tax ruling was left without consideration (in the years: 2012 - 77 applications out of 57; 2013 - 41 applications out of $34 ; 2014$ - 46 applications out of 32; 2015 - 20 applications out of 19; 2016 22 applications out of 17 ).

The presented data confirm that the conditions to be met by the application for issuing a general tax ruling are not so difficult to meet as they are 'prohibitive', hence the moderate activity of the MF in issuing rulings ex officio may be surprising. Especially that in the analyzed period the number of tax rulings issued in individual taxpayer cases increased successively $(24,229$ in $2008,28,153$ in $2009,30,920$ in $2010,35,929$ in 2011 , 36,816 in 201236,143 in 2013, 37,891 in 2014, 37,710 in 2015), which were often contradictory $^{32}$ and also erroneous, thus repealed by administrative courts. ${ }^{33}$ The decrease in the number of these tax rulings took place in 2016-2017 (up to 34,151 in 2016 and 25,718 in 2017). The reason for the decrease in the number of issued tax rulings should be seen not so much in improving the quality of the Polish tax law, guaranteeing the legal security of taxpayers, as in the introduction into the TO in 2016-2017 new legal regulations allowing to, among others file a so-called joint application (Article $14 \mathrm{~s}$ of the TO), which may be requested by at least two interested parties who are in the same factual circumstances or are to participate in the same future event. The competent authority may also refuse to issue an individual tax ruling, if the anti-avoidance clause applies in the case described in the application, or if an attempt to avoid taxation is detected (Article $14 \mathrm{~b} \$ 5 \mathrm{~b}$ of the TO). On this basis, in 2017, the Director of the NTI issued 650 decisions refusing to issue a tax ruling. It seems that the fear of the effects of this regulation itself may lead to a decrease in the number of applications. In addition, the provisions of the TO provide that no ruling shall be issued if the factual circumstances or future events presented in the 
application correspond to an issue being subject to a general tax ruling issued in the same legal state. In such a case, the Director of the NTI issues a decision stating that general tax ruling is applicable to such a situation or event (Article $14 \mathrm{~b} \S 5 \mathrm{a}$ of the TO). In 2017, the Director of NTI issued 491 decisions on the application of general tax ruling, whereas NTI offices received a total of $29,599^{34}$ applications for an individual tax ruling. It seems that the purpose of this regulation is not only to reduce the impact of requests for individual tax rulings, but also to ensure greater activity on the part of the MF in issuing general tax rulings, which unfortunately cannot be observed.

Therefore, it should be stated that, although the regulations regarding the tax rulings of the MF have been significantly improved and clarified since the day of their introduction, the provisions of the TO do not contain regulations which would indicate what criteria should be followed by the MF while assessing the need for a general tax ruling. Even if there are discrepancies in the assessment of identical factual circumstances between the views presented in the case law of administrative courts and the views presented by tax authorities, the minister is not required to issue a general tax ruling consistent with the case law of these courts or to amend an existing one ${ }^{35}$ which should be considered as a weakness of this regulation. For this reason, it should be recognized that the regulations concerning the interpretation of tax law provisions and the practice of issuing them do not sufficiently ensure the main purpose of a tax ruling, i.e. ensure uniformity of application of tax regulations by the tax office. 


\section{References}

1 Uniform text: Journal of Laws 2018, item 800, as amended.

2 Bogumił Brzeziński, Advance tax rulings jako instytucja prawa podatkowego [Advance tax ruling as an institution of tax law], 13-21, in Roczniki Nauk Prawnych [Annals of Juridical Science], no. VII (1998).

3 Zbigniew Kmieciak: Procesowe gwarancje ochrony interesu podatnika [Procedural guarantees protecting taxpayer's interest], 9-28, in Kwartalnik Prawa Podatkowego [Tax Law Quarterly], no. I (2000).

4 Journal of Laws, no. 137, item 926.

5 Henryk Dzwonkowski, Indywidualna interpretacja prawa podatkowego [Individual tax ruling], 18-23, in Monitor Podatkowy [Tax Monitor], no. 4 (2003).

6 Jacek Brolik, Kontrowersyjne kompetencje Ministra Finansów $w$ dziedzinie stosowania prawa podatkowego [Controversial competences of the Minister of Finance in the field of application of tax law], 6, in Przeglad Podatkowy [Tax Review], no. 7 (1999).

7 Leonard Etel (eds.), Prawo podatkowe [Tax Law], 216-217 (Warsaw, Difin 2008).

8 Constitutional Court, K 10/93. All verdicts of the Constitutional Court are available at trybunal.gov.pl/ wyszukiwarka/ (accessed 4 June 2018).

9 Constitutional Court, K 47/05.

10 The Act of 12 September 2001 on the amendment of the Act - Tax Ordinance Act and on amendments of certain other acts (Journal of Laws, no. 169, item 1387).

11 Cezary Kosikowski et al., Ustawa Ordynacja Podatkowa. Komentarz [Tax Ordinance Act. Commentary], 78 ( $2^{\text {nd }}$ edition, Warsaw, Dom Wydawniczy ABC 2004).

12 Roman Szumlakowski, Zasady prawne postępowania podatkowego organów administracji podatkowej $\mathrm{w}$ relacjach $\mathrm{z}$ podatnikiem [The legal principles of tax proceedings of tax administration authorities in relations with the taxpayer], 203-213, in Paweł Borszowski (eds.), Podatnik versus organ podatkowy [Tax payer versus tax authority] (Wrocław, Prawnicza i Ekonomiczna Biblioteka Cyfrowa 2011).

13 Justyna Bauta, Ryszard Sowiński, Ochrona podatnika przed skutkami błędnej interpretacji prawa podatkowego [Protection of a taxpayer against the consequences of misinterpretation of tax law], 53, in Przeglad Podatkowy [Tax review], no. 10 (2001).

14 Constitutional Court, $\mathrm{K}$ 4/03.

15 The Act of 2 July 2004, Provisions introducing the Act on the freedom of economic activity, Journal of Laws of 2004, no. 173, item 1808.

16 Now: Court of Justice of the European Union.

17 The Act of 16 November 2006 on the amendment of the Act - Tax Ordinance Act and on amendments of certain other acts, Journal of Laws, no. 217, item 1590.

18 The Act of 16 November, 2016. Regulations introducing the Act on the National Tax Administration, Journal of Laws of 2016, item 1948.

19 Art. 14a $₫ 1$ amended on 1 January 2016 by the Act of 10 September 2015 on the amendment of the act - Tax Ordinance Act and certain other acts, Journal of Laws of 2015, item 1649.

20 Act on 16 September 2011 on the reduction of certain obligations of citizens and entrepreneurs, Journal of Laws of 2011, no. 232, item 1378.

21 At present the template is regulated by the Regulation of the Minister of Finance of 17 February 2017 on the template for the application for a general tax ruling and how to pay the application fee, Journal of Laws of 2017 , item 352.

22 Hanna Filipczyk: Interpretacja ogólna na wniosek - nowe rozwiązanie w Ordynacji podatkowej [General tax ruling upon request], 11-15, in Monitor Podatkowy [Tax Monitor], no. 3 (2012).

23 The Voivodship Administrative Court in Warsaw: III SA/Wa 3379/12. All verdicts of administrative courts are available at orzeczenia.nsa.gov.pl/cbo/query (accessed 4 June 2018).

24 Supreme Administrative Court, II FSK 2253/13. 
25 Directors of Tax Chambers: in Bydgoszcz - in the field of personal income tax; in Katowice - in the field of corporate income tax and excise duty; in Poznan - in the field of tax on goods and services; in Warsaw - in the area of tax on civil law transactions, inheritance and donation tax, and the provisions of the Tax Ordinance Act; in Lodz - in the scope of other applications, irrespective of the place of residence or registered office of the applicant. Regulation of the Minister of Finance of 27 December 2011 on authorizing the issuance of decisions on leaving without consideration the applications for general tax rulings and for performing certain activities related to submitted applications (Journal of Laws, no. 296, item 1757).

26 Regulation of the Minister of Economic Development and Finance of 21 February 2017 on authorizing the issuance of decisions on leaving without consideration the applications for issuing general tax rulings and performing certain activities related to submitted applications, Journal of Laws of 2017, item 341.

27 Przemysław Krzykowski, Urzędowe interpretacje prawa podatkowego a system źródeł prawa [Official interpretations of tax law and the system of sources of law], 28-29, in Kwartalnik Prawa Podatkowego [Tax Law 2uarterly], no. 3-4 (2005).

28 The Voivodship Administrative Court in Rzeszow, I SA/Rz 1153/13.

29 Art. $14 \mathrm{e} \$ 1$ p. 1 of the TO amended on 1 January 2016 by the Act of 10 September 2015 on amendment of the act - Tax Ordinance Act and certain other acts.

30 Leonard Etel et al., Ordynacja podatkowa. Komentarz [Tax Ordinance Act, Commentary], 183, (Warsaw, Wolters Kluwer, 2017).

31 Polish Parliament of the VII term: Justification of the draft law amending certain acts to improve the legal environment of entrepreneurs, paper no. 994.

32 Compare: Individual tax rulings of the Tax Chamber Director in Warsaw no. IPPB5/423-200/09-2/DG, no. IP-PB3-423-59/08-2/GJ, no. IPPB5/423-788/10-5/DG as well as: Individual tax rulings of the Tax Chamber Director in Katowice, no. IBPBI/2/423-709/09/SD and Individual tax rulings of the Tax Chamber Director in Bydgoszcz annulled by The Voivodship Administrative Court in Gdańsk, I SA/Gd 1311/10.

33 Compare: Supreme Administrative Court, II FSK 1242/16; I FSK 2140/15; I FSK 726/16; I FSK 382/16; I FSK 350/16; I FSK 307/16.

34 All the data come from the Information on the Tax Information Office activities for the years: 2013, 2014, 2015, 2016, and the Information on the Revenue Information Office activities for the year 2017, www.kis. gov.pl/dzialalnosc/raporty-z-dzialalnosci (accessed 28 May 2018), and Official Journals of the Ministry of Finance and Official Journals of the Ministry of Economic Development and Finance for the years 20072018, www.mf.gov.pl/ministerstwo-finansow/minister-finansow/dziennik-urzedowy (accessed 28 May 2018), www.mf.gov.pl/ministerstwo-finansow/minister/dziennik-urzedowy-ministra-rozwoju-i-finansow (accessed 27-28 May 2018).

35 The Ombudsman, RPO-630990-VI/09/AB, www.rpo.gov.pl/sites/default/files/Informacja_kwartalna_o_ pracy_RPO_pazdziernik_\%E2\%80\%93_grudzien_2009_r.pdf (accessed 22 May 2018). 